\title{
Schooling entrepreneurs: Entrepreneurship, governmentality and education policy in Sweden at the turn of the millennium
}

\section{Magnus Dahlstedt, Fredrik Hertzberg}

Abstract: Departing from Michel Foucault's concept of governmentality, the focus of this article is the introduction of entrepreneurial education in Swedish education policy at the turn of the millennium. We analyze the various meanings attached to the concepts of "entrepreneur" and "entrepreneurship" in education policy documents, as well as the main arguments for introducing entrepreneurial education. In policy documents, the "entrepreneur" is portrayed as being flexible, creative, enterprising and independent, as having the ability to take initiative, solve problems and make decisions. Here, there is an emphasis made on economical utility, and its priority over other values. With an increasing mobilization of entrepreneurship in school, previous pedagogical and educational doctrines - focusing on equality, universalism and redistribution - are challenged. Other visions, stating other educational purposes and goals emerge. In the vision of the entrepreneurial school, it becomes logical and natural to emphasize the value education has for the economic system. In conclusion, entrepreneurial education may be seen as a particular kind of governmentality, connecting students and their subjectivity to the rationality of the market - fostering subjects in line with the imperatives of the "advances liberal society".

Key words: entrepreneurship, entrepreneurial education, governmentality, education policy, Sweden

\section{Introduction}

The focus of this article is the introduction of entrepreneurial education in Swedish education policy at the turn of the millennium. Even though 
the focus is on Sweden at the millennium, the same processes could be identified in a number of other countries throughout the world. An emphasis on entrepreneurship in school is part of a broad, international trend in educational policy (Mahieu, 2006). In recent decades, entrepreneurship has been understood to be more and more important in order for each country to succeed in the tough competition brought on by today's globalized "knowledge-based society". Sweden is no exception from this development - the basic argument has been the same in Sweden as in many other countries.

In this context, the role of education is crucial. Since the 1990s, there has been a lively discussion in Sweden about the importance of schools in making the Swedish population more "entrepreneurial". When revising the existing curriculum in 2009 , for example, the right-wing government made clear that the issue of entrepreneurship is one of the main priorities.

THE GOVERNMENT CONSIDERS that entrepreneurship should be a theme running through the entire education system. [...] The basis for developing an entrepreneurial approach should be established early on, for example by stimulating girls' and boys' curiosity, creativity, confidence and ability to make decisions. (The Government Offices, 2009, p. 9)

Here, the entrepreneur is described in a certain way. As in many other contexts, the entrepreneur is ascribed a number of strongly desirable characteristics - "curiosity, creativity, confidence and ability to make decisions". The entrepreneur is portrayed as a contemporary hero. In order for society to survive, the school has to make the students into entrepreneurs, embracing the qualities and abilities attributed to the entrepreneur. An increasing emphasis on entrepreneurship in school illustrates an on-going shift in understanding the role of education in society and the way in which education should be organized, taking place not only in Sweden but in many other countries. Departing from Michel Foucault's concept of governmentality, the aim of this article is to analyze the various meanings attached to notions of "entrepreneur" and "entrepreneurship" contained in education policy documents as well as the main arguments for introducing entrepreneurial education. How is the "entrepreneur" constituted as a subject? What are the characteristics, qualities and abilities of this particular subject? How should this subject be educated? What different techniques are mobilized in the name of "entrepreneurship"? What are the main arguments for introducing entrepreneurial education?

In the first part of the article, we present the theoretical perspectives informing our analysis. Then we briefly contextualize the discourse on entre- 
preneurship education by outlining the major education policy changes that have taken place in Sweden over the past two decades. With these changes as a starting-point, we then go on to further analyze the discourse on entrepreneurship in Swedish education policy; how the issue of entrepreneurship was introduced; the main reasons for introducing entrepreneurship in school; how the entrepreneurial subject is created in policy documents and how this particular subject is supposed to be educated. Finally, the main findings of the analysis are summarized and set in a broader political context. What do current ideas about entrepreneurship, and particularly the role of entrepreneurship in school, tell us about on-going transformations in governing education, individual and society?

\section{Theoretical Framework}

The starting point for our contribution is the theorization of governmentality that has been developed in the wake of the work of Michel Foucault (Foucault, 1991; Dean, 1999; Rose, 1999), but first and foremost the ways in which the concept of governmentality has been related to issues of learning and education (Hultqvist \& Petersson, 2000; Fejes \& Nicoll, 2008; Popkewitz \& Brennan, 1998). Conceptually, the term itself, in combining the two words govern and mentality, captures more complex forms of governing than those usually referred to in a conventional understanding of "government" (Rose, 1999). One crucial difference is found in the way that those who constitute the "objects" of governing are not viewed as "passive" targets. Instead, governing in itself is said to form the "objects" of governing. Thus, the concept captures the "mentality of government", i.e. how different regimes of truth are related to various political procedures and governmental techniques (Dean, 1999).

According to Foucault (1991), governing does not originate from or 'belong' to the state apparatuses. Governing is rather made up of a broad repertoire of technologies of government operating throughout the entire social field, crossing boundaries for instance between public and private, state, market and civil society, political and commercial, citizen and consumer. Governing is productive as well as restrictive (Dean, 1999). Here, Foucault (1988) differentiates between technologies of power and technologies of the self. One technology does not rule out the other; rather, the different technologies are often intertwined (Dean, 1999). While technologies of power "determine the conduct of individuals and submit them to certain ends of domination", technologies of the self relate to people's self-formation the way they produce themselves as citizens. These techniques 
permit individuals to effect by their own means or with the help of others a certain number of operations on their own bodies and souls, thoughts, conduct, and way of being, so as to transform themselves in order to attain a certain state of happiness, purity, wisdom, perfection, or immortality. (Foucault, 1988, p. 18)

The question of how tomorrow's citizens are produced is constantly reappearing in new forms. According to Nikolas Rose (1996, p. 41) we are today living in an "advanced liberal society", which "does not seek to govern through 'society', but through the regulated choices of individual citizens, now constructed as subjects of choices and aspirations to self-actualization and self-fulfilment". Governing involves constant responsibilization (Rose, 1999), i.e. the creation of "responsible citizens" who take charge of the entire course of their own lives (from education and work, politics and housing, to family and leisure activities) on the basis of their own ideals, circumstances and ambitions. The rationality of these neo-liberal interventions is "implanting in citizens the aspiration to pursue their own civility, wellbeing and advancement" (p. 40), i.e. the creation of individuals who are, by their own efforts, motivated, willing and able to take initiative. The formation of "responsible citizens" involves a wide range of technologies, actors, systems of knowledge, authority and expertise, operating in a number of different fields.

The school is of course still an important site for this on-going formation of the "responsible citizens". Although the school in this respect is still an important arena in society, the school has never been an arena clearly separated from the rest of society. Rather, the school may be viewed as a domain for a wide range of learning technologies, involving a number of different actors, operating both inside and outside of the school. These processes of learning, however, are not localized on specific places or delimited institutional arenas, such as the school. They are rather distributed across the entire social field and involve actors operating in and through various arenas. "Today, education everywhere in the world is not just a question of what is taught in school, but is, in the name of lifelong learning, something that permeates the governance of all social activities" (Olsson \& Petersson, 2008, p. 62).

Learning how to become a "responsible citizen", inside as well as outside school, is an on-going process of normalization, where some abilities or characteristics are emphasized as good and desirable - in relation to those defined as deviant, problematic and in need of "retraining" (Popkewitz \& Brennan, 1998). Today, this citizen is portrayed as someone who is well adapted to the particular conditions and expectations of the "advanced lib- 
eral society" of today, i.e. a citizen who is flexible, employable and responsible. Traditionally, teaching has been based on hierarchical relations between teachers and students, where students have been shaped into citizens through a series of disciplinary techniques. More recently, and particularly in the last decades, technologies that Foucault refers to as "technologies of the self" have become increasingly more prominent in the schools as more and more attention has been paid to the importance of motivating students, building their confidence and willingness to take initiative (Hultqvist \& Petersson, 2000).

\section{A Changing Education Policy Regime}

Since the Second World War, the Swedish education system has undergone major changes. Education was a cornerstone of the "Swedish model", the Social Democratic welfare model that emerged in Sweden in the postwar period (Esping-Andersen, 1990). The organisation of the Swedish education system rested on the main pillars of non-segregation, social levelling, equality, general citizen-competence, and public responsibility for education (Lindensjö \& Lundgren, 2000). One overarching objective of education policy in the "Swedish model" was to gradually level social and economic gaps and thereby to counteract the most polarising effects of the market. Swedish education policy was dominated by a view of education as a "public good" (Englund, 1994). Under such an education policy, every individual should be guaranteed the right to equal education, understood and institutionally underpinned as a fundamental social right.

However, in the end of the 1980s, the perception of the role of education in Swedish politics changed. From having been regarded as a "public good", schools have come to be seen more as a "private good" (Englund, 1994). The focus shifted towards individual choice, parental responsibility for education, efficiency and competition, together with the development of individual competence as guiding principles of how schools should be run. An increased emphasis on the principle of freedom of choice is a central feature of the education reforms implemented in the 1990s, for example. The principle of equality, in the sense of equal outcomes, was gradually replaced by the principle of equity, in the sense of opportunities (Lindensjö \& Lundgren, 2000).

An important part of the political context of this shift was also an idea that became more widely held during this time, according to which education was seen as an investment whose rewards could be evaluated in terms of increased growth and international competitiveness. In this context, the focus for educating citizens was increasingly directed toward the labour 
market. The overall objective of education is increasingly in creating competitiveness. The meaning of education is hereby changed, from a fundamental social right to a commodity, in relation both to the population inside of the borders and outward to the surrounding world. As in many other countries, it was more common to described education in terms of "human capital", i.e. as some kind of human "raw material" which can be refined in order to make profit (Simons \& Masschelein, 2008; Gillies, 2011).

If we summarize the main lines of development in Swedish education policy over the past two decades, one can thus say that during this period there has occurred a significant change in the way in which education is imagined, in terms both of its design and its role in society. From essentially having been imagined as a social collective project, with the means to redistribute resources and to deal with socio-economic divisions in society, education has increasingly come to be defined as an individual project, with an increasing emphasis on individual choice, responsibility and equivalence as the guiding principles shaping education policy.

\section{Entrepreneurship on the Agenda}

It is in this particular policy context that the concept of entrepreneurship is introduced. In the 1990s and at the turn of the new Millennium, the concept of entrepreneurship has become a key word in Swedish education discourse. Some of those arguing for far-reaching changes in the Swedish educational system strongly emphasized the importance of entrepreneurship education (Nyström, 1999; Johannisson et al., 2000). In this context, the entrepreneur is presented as an untouchable person, almost like a contemporary hero - "a bearer of the light, and provider of the good", a "flaming torch amidst the darkness of the grinding monotony of bureacratised undertaking" (Styrhe, 2005, p. 170). With such explicitly positive connotations, the concept becomes more and more attractive and appears in a number of different contexts, describing a wide range of social phenomena (Tesfahuney $\&$ Dahlstedt, 2008). In this way, the vocabulary of economics carried over from the economy to other sectors of society (cf. Lindqvist, 2001).

So what were the main arguments for introducing the concept of entrepreneurship in Swedish educational policy? When the issue of entrepreneurship began to have a greater impact on educational discourse in the middle of the 1990s, the argument for introducing teaching of entrepreneurship was mainly related to the needs and demand of the labour market. The goal was to make young people more willing to start their own businesses after graduation, as it was argued that this would have positive effects for the labour market, the economy and thus Swedish society at large. We can see 
a clear example of this line of argument in the following quote, taken from the first governmental inquiry on entrepreneurship in school:

Globalization and rapid technological changes are making the work organizations more flexible, which increase the need of energetic individuals. The requirement for individual problemsolving ability, ability to take initiative, ability to be creative and flexible increases, as does the need for self-reliance. In order to secure growth and jobs, we simply have to develop a greater element of entrepreneurship in the sense of individual enterprise in the whole society. There is a general consensus that the foundations of entrepreneurship and enterprise have to be developed in school. [...] It is essential that developing a more entrepreneurial educational system in various ways is a priority and that information about how entrepreneurship can be promoted is spread at various levels in the educational system. (Ds 1997: 3, p. 3)

This quotation illustrates several recurring themes in the discourse of entrepreneurship taking shape in the mid-1990s. One of these themes is the idea that fundamental transformations in the outside world make the mobilization of entrepreneurship in the educational setting unavoidable. The quotation above describes current historical processes in terms of an almost compelling logic: "Globalization and rapid technological changes are making", "the foundations of entrepreneurship and enterprise have to be developed in school". In this light, entrepreneurship appears, not as a priority of education policy, but rather as something necessary or compulsory (Dahlstedt \& Tesfahuney, 2010). The quotation clearly indicates that it is, first and foremost, the demand of the Swedish labour market that motivates the stronger emphasis on entrepreneurship. It also indicated that it is the school that shall ensure that the workforce of tomorrow has developed the desirable attitudes or mentalities, namely "individual enterprise". The key notions emerging in the discourse of entrepreneurship are growth and productivity. Previously, the desire to meet the requests for economic growth and productivity of the market in education policy has primarily been part of a right-wing policy agenda (Lundahl, 1997). However, regarding the desire to introduce entrepreneurship in educational settings, there has been a strong political consensus in 1990s and the early 2000s: "There is a general consensus that the foundations of entrepreneurship and enterprise have to be developed in school".

The above quotation also illustrates another recurring theme in the discourse on entrepreneurship education, namely educating the entrepreneur- 
ial subjects, with the promotion of certain values, abilities and characteristics. It is these values, abilities and characteristics that entrepreneurial education seeks to develop among the students. Creativity, independence, flexibility, the ability to take initiative, problem-solving skills and self-confidence are some of the characteristics that the students are encouraged to develop through the teaching of entrepreneurship. Here, advocates of entrepreneurial education imagine a teaching with the transformative power to change the individual in a tangible and very positive way (Leffler, 2006; Mahieu, 2006). This wide and encompassing change is about nothing less than changing the attitudes or self-conception of the individual.

In a number of policy documents from the 1990s onwards, there is a strong desire to make self-employment appear as a more desirable, feasible and reasonable alternative for the young people about to enter the labour market. For example, influencing the attitudes among young people is one of the most important motives for the promotion of entrepreneurship in the Swedish school system suggested in the 1995 Employment Bill.

Attitudes play an important role in enterprise and entrepreneurship. [...] An increased emphasis on entrepreneurship in the educational system is motivated not only by the need for a more business-friendly environment. An enterprising culture, in a broad sense, includes general skills such as creativity, initiative and flexibility. The ability of problem solving is designated as a central objective in the new curricula. (Prop. 1995/96: 222 $\S 5.2 .2)$

Relating this line of argument to the theorization of governance and subject formation based on the writings of Foucault indicates a certain kind of governing, made possible by the formation of the students' mentalities, personalities or selves - i.e., governmentality. Entrepreneurship, as described in the policy documents, is about shaping the entrepreneurial personality, willing and inclined to identify themselves according to current notions and ideas about how such a subject is constituted. The main question, then, becomes how students should develop a will to take initiative, to be motivated, to realize their potential and find their inner drive. As part of strengthening the autonomy, self-reliance, willingness to learn and motivation among the students, there is a broad repertoire of "technologies of the self" mobilized and educational interventions directed at the students' selves.

The passage immediately following the above quotation introduces a third recurring theme in the discourse on entrepreneurship in schools, namely the idea that the school should be engaged in close collaboration or "part- 
nership" with a range of stakeholders in the surrounding community, particularly the local labour market.

But attitudes towards entrepreneurship are also formed in the local community, outside school. A school promoting entrepreneurship should therefore be an integrated part of the rest of the community. The municipalisation of the school, together with the high school reforms, has opened the door for new solutions. We also see the emergence of different forms education with a stronger emphasis on collaboration between school and work, as well as adaptation to local conditions. It is important that this trend continues and is encouraged. (Prop. 1995/96: $222 \S 5.2 .2$ )

When the idea of entrepreneurship in school was developed during the mid-1990s, it was explicitly related to the issue of collaboration between the school and local stakeholders, which was one of the main arguments for the general decentralization that was carried out within the Swedish school system (Lindensjö \& Lundgren, 2000; Dahlstedt, 2009). The idea of the "collaborating school" appear in many policy documents in the 1990s, dealing not only with entrepreneurship, but with the challenges facing the Swedish school system as a whole, on the eve of the new millennium.

The relationship between school and work has changed. The school can no longer give definite tickets for specific professions that students can see in front of them, which may motivate them working hard in school. Working life has to be involved and take responsibility for the school. With more responsibility there should be greater opportunities to participate in and influence the content as well as the organization of teaching. [...] The school has much to learn from activities outside of the school, the local labour market, institutions and people in the local community. (Government Communication, 1996/97: 112, p. 31)

Here, collaboration with local communities, and not least the local labour market, is described in terms of necessity. "Working life has to be involved and take responsibility for the school". In other words, it is presented as selfevident that the market should have access to the domain of the school, as the market is imagined to have a legitimate responsibility when it comes to "influencing the content as well as the organization of teaching". The desire to foster entrepreneurship highlights the importance of the local context in education policy of the 1990s, as entrepreneurship as such was assumed to 
have great benefits in terms of local cooperation. The metaphor framing this particular understanding of the school and its role in society and in the local community was that of the "open school".

That the school is open can mean several things: that it is open to all students and to all students' experiences, that it is characterized by an open discussion where everyone gets their say and are treated with respect, that the teaching opens itself up to the resources available in the surrounding community, that it is open for parents to come to school and influence its work and so on. One can also speak of the open school as a place that can be utilized by the local community, a place also in a physical sense: the school buildings. If the school is opened up in this way, it also opens up for contacts and influences, which can enrich the school practice. We believe that these forms of openness are connected, and when the boundaries between the school and the community are dissolving, the school will be characterized by openness in several respects. (SOU, 1997: 121, p. 220)

The idea that different actors should collaborate, in and around the school as well as in relation to other arenas, can be seen as part of a specific form of governance, a kind of "government through community" (Rose, 1999 , p. 176), made possible by invoking and mobilizing the local community. Through articulating the school as entrepreneurial it is envisioned that new networks and relationships will emerge in the local context, between the school and other actors in the community. In this local context learning takes new forms. The school can no longer be understood as an isolated arena, but should rather be seen as a meeting place where a variety of actors participate and engage with one another (Dahlstedt, 2009; Dahlstedt \& Hertzberg, 2011). In the name of collaboration and partnership, new domains of governing and control are developed, with certain forms of responsibility and accountability, involving not only the state, but a wide range of stakeholders, NGOs, parents, local activists, businesses (Popkewitz, 2002; Andersson, 2006).

The focus on community was not only prevalent in educational policy. Similar arguments were also mobilized in economic policy. The community and the small-sized company were regarded as social environments in which ideas, products and services would flourish and develop, since it was held that the human relations established in this small-scale context was characterized by trust and recognition of mutual interests, not only economic considerations. It was maintained that the accumulation of social capital in this context strengthened long-term cooperation as well as the devel- 
opment of products and the accumulation of value. Moreover, it was also held that the local context and the small company was more flexible, being more adaptive to changing conditions and constituting a less constraining social milieu, thus permitting adjustments in the production of commodities or services (Piore \& Sabel, 1984). To summarize: in the economic policy of the time, it was often maintained that the level of creativity and flexibility increases at workplaces where the employees are parts of a tight-knit web of social relations. Thus, it primarily emphasized economic development at the local and regional level.

The emphasis on trust in this particular context was part of a more general idea or argument that became increasingly prominent in social science and social policy during the 1990s, in which it was argued that strong local network contributes to the creation of trust and loyalty between individuals, as well as between the individual and societal institutions. It was held that the mobilization of communal social forces through cooperation in the local communities also promoted democratic and economic development (Dahlsted, 2009). In social and educational policy, a kind of "government through community" was heralded, which - in the name of the local community - set up a domain whose energies and resources could be mobilized and put in place for initiating all kinds of governing techniques (Rose, 1999, p. 176). The emphasis of the local community had a major policy impact, not the least because it was an idea portraying society as an idyllic social order, where there is a range of natural, reciprocal relationships between different local actors developed. Nevertheless, this seemingly "natural" social order in itself is a result of various governing techniques (Rose, 1999, p.168).

Thus, economic and education policy converged during the 1990's through a focus on the local context and cooperation between public, voluntary and private actors and bodies. The emphasis on entrepreneurship in school took shape in the interface between those policy areas (Leffler, 2006; Mahieu, 2006). In this matter, the drive for entrepreneurial learning differs from other articulations in Swedish education policy at the time. The initiative was not taken at the Ministry of Education but at the Ministry of Enterprise (Mahieu, 2006). For example, the first governmental inquiry on entrepreneurship at school (Ds, 1997, p. 3) was carried through by order of the Ministry of Enterprise as a part of their policy development. Because of this, the aims and learning out-comes of the teachings in entrepreneurship at primary and secondary school was articulated outside of and external to the curricula in force.

The venture on entrepreneurship in primary and secondary education that begun in the 1990s is an international phenomenon and a broad trend in international educational policy (Henry et al., 2011), powerful supranational 
bodies such as OECD and EU identified an increasing need for entrepreneurial skills and behavior in their member states already at the beginning of the decade, for example. The support for entrepreneurship has been a key aspect of the action and development plans in the Lisbon Strategy developed by the EU and devised in 2000, which aims at making EU the most competitive and dynamic knowledge-based economy in the world. Although these bodies lack formal right of decision and influence of Swedish educational policy, they nevertheless exert certain influence over it, for example through indirect steering instruments such as national comparisons and benchmarking practices (Mahieu, 2006).

\section{Instructions about, in or for Entrepreneurship}

As regards the teaching of entrepreneurship, there have been different views on how it can or should be formed (Holmgren \& From, 2005; Mahieu, 2006; Svedberg, 2007). Which are the most appropriate learning objectives, and what can or should they actually contain? To clarify these differences, we first make a distinction between teachings of entrepreneurship in a narrow or broad sense, which is dependent on how entrepreneurship is defined (Stevenson \& Lundström, 2002; Leffler, 2006). This division elucidates the divergence in learning outcomes. Entrepreneurial learning in a narrow sense focuses on knowledge in economy, while entrepreneurial learning in a broad sense is related to education in general. The first approach consists primarily of learning about entrepreneurship as a matter of business, i.e. how to start and manage your own company. In the second and broad approach, the learning set out to mould students who have the dispositions described as characteristic of "entrepreneur" - he or she who is enterprising, creative and flexible, and has the ability to make decisions and develop ideas. In present-day education policy, particularly the latter, broader definition of "entrepreneur" has gained a hearing, a trend that has become increasingly strong during the 2000s (Mahieu, 2006).

Another way to clarify the differences between different forms of learning about entrepreneurship is to make a distinction between education about, for and in entrepreneurship. To a greater extent than the last one, this division takes up differences with regard to teaching content. Based on this division, Nutek, the then Swedish Agency for Business Development [SABD], describes the different approaches to teachings in entrepreneurship:

Training about entrepreneurship includes knowledge on the nature of and conditions for entrepreneurship. It provides a deeper understanding and insight into the thinking and actions of the entrepreneur. Many university courses on entrepreneur- 
ship can be attributed to this category. The effect of this type of training is an increased understanding in the community for entrepreneurs, and is essential for the shaping of a social climate and sets of rules and regulations, which are beneficial for entrepreneurs. Still, it makes relatively few participants become entrepreneurs and start to realize their ideas.

Training in entrepreneurship is often based on a concrete idea, realized in a more or less real-life situation. It develops the skills and competencies, which gradually are needed for the development of ideas. A good example of this is a course on how to start one's own business based on a specific business idea. [...] It's all about the practical development of ideas, in order to establish and use the skills and attitudes required for the practical realization of a current idea.

Training for entrepreneurship (the spirit of entrepreneurship) includes preparatory training for the development of attitudes, abilities and attitudes that generates dynamic thinking and action. In here, one will also find exercise in active responsibility, for oneself and others, as well as the development of ideas, project management, etc. Creativity is sometimes a separate training element, but usually comes as a natural consequence and outcome, in the practice of above-mentioned exercises, as they require new ideas to solve real-world situations. Training for entrepreneurship enhances the entrepreneurial spirit, which is the basis for professional work in the form of employment or self-employment. (Nutek, 2007, p. 24f)

Thus, education about entrepreneurship is primarily seen as a concern for universities and colleges, while education in and for entrepreneurship is seen as part of the primary and secondary education. Education in entrepreneurship is usually conducted through practice, for example by pupils themselves or with their peers, in which they develop a product or service, which can be sold in a market. Then, they have to take responsibility for the step from idea to innovation. It might also be that they, with varying degrees of involvement in real business, take care of regular business activities, such as a school cafeteria. In this case, entrepreneurial learning is based on the principle of learning to take responsibility through practice, i.e. learning by doing. On the other hand, training for entrepreneurship is more theoretical in nature and combines practical exercises with teaching activities, 
aimed at the shaping of entrepreneurial virtues such as creativity, autonomy, playfulness and so on.

This threefold nomenclature of entrepreneurial education has gained influence in the entrepreneurship projects carried through in Swedish primary and secondary education. The SABD was the leading actor in entrepreneurial education during at the beginning of the new millennium, and between 2005 and 2008 they organized the up to then most comprehensive and extensive program for this kind of activity, the National entrepreneurship program (Nutek, 2007, 2008). This nationwide project had the overall objective to increase the "entrepreneurial spirit" among young people, in order to make them inclined to regard entrepreneurship as a self-evident alternative to employment. As the agency wanted to create a "common thread" in the Swedish education program, they targeted all educational institutions - from kindergarten, to primary and secondary schools and higher education.

The initiative has its foundation in an entrepreneurial approach that runs from preschool to college and university. When entrepreneurship runs like a thread throughout the education system, it gains impact. An individual shaped by entrepreneurial learning in school is an asset for the existing organizations in the labour market. Also, entrepreneurship gives the individual the courage to fly - to start her own business and realize her dreams. Creative abilities come forward and create success in business. Which way one chooses to walk, creativity, playfulness and courage is important properties that carries the individual, and leads to an increase in the number of new companies, and to the improvement of the functioning of organizations. (Nutek, 2007, p. 11)

Thus, the ambition of SABD was to "mainstream" entrepreneurship in the education system. Education in entrepreneurship is expected to reach every pupil and every student, at all ages, and present at every level, thus constituting something more than a mere addition or supplement. The SABD is very clear on this in their statement of learning outcomes, and they also have a clear picture of what they want to produce. First of all, the educated entrepreneurial student will be an asset for existing companies, and incitements for the establishment of new companies will be created. Second, it develops the whole personality - entrepreneurship gives the individual courage to "dare to fly" and realize life dreams, and awaken his or her creativity and playfulness. Again, those who propagate for entrepreneurship in education have high demands - partly because the knowledge is of value to all, 
the individual and for collective, partly because it claims ability to change the learner in his or her entirety, in a positive and beneficial way. Thus, it is evident that it was the "broad" definition of entrepreneurship education that guided the work of SABD.

During the last ten years, a number of municipalities and/or schools have voluntarily decided to carry through a number of different entrepreneurship programs. Within the framework of SABD's program, a number of strategies have been developed at the local level in order to fulfill its learning outcomes (the following section is based on the presentation in Nutek 2008). Municipalities, counties and/or separate schools developed different ways of working. In certain regions, comprehensive programs for all schools in the region were established. In Stockholm County, civil servants in the municipal administration, career counselors and teachers received financial support for developing local plans for the implementation of entrepreneurial teaching at their schools. In other counties and municipalities, local school projects were inaugurated, in which specific models for entrepreneurial learning was developed, such as fairs, exhibitions and other temporary projects. In some cases, voluntary associations were found which promoted the interest for natural sciences, technology, innovations and problem-solving among youth. These associations were bodies external to the school, and were invited as a complement to the regular instructions.

Other projects aimed at improving the relations between schools and the local labour market. In some cases, the development of these projects was fuelled by an existing dissatisfaction with their own work experience program, or a perceived lack of contact between school and working life. In the city of Västerås, for instance, local companies became sponsors for different classes in the fifth year of primary school. Subsequently, these sponsors followed the class during several years. The companies were recruited via the parents of the children. Representative of the company was invited to the instructions, in subjects which easily were connected to the business of the company. During the last year at primary school, the contact was intensified and the pupils were invited to the company in order to make their project work, with topics related to the enterprise of the company. In and through this cooperation, networks were established between school, parents and companies. Another example is found in the small town of Tingsryd, where the municipality gave local companies an opportunity to express their views on the conditions of work and entrepreneurship to teachers as wells as pupils, among other things through the arrangement of educational visits at the company for the teachers, along with the education of teachers, headmasters and career counselors in entrepreneurship. The company representatives also got the opportunity to take part in the design of teaching 
material. Moreover, a number of interfaces between school and the working life were created, such as the education and certification of 50 "vocational ambassadors", which should functions as contacts between these social spheres.

A fourth form of projects within the national program of SABD aimed at integrating "entrepreneurial dispositions" in the instructions. The content of these projects was diverging. In some cases, education about entrepreneurship was introduced through the mediation of knowledge on the nature of and conditions for entrepreneurship. In other cases, education in entrepreneurship was carried out, partly in the form of regular classroom teaching focusing on topics such as business strategies, marketing, economy, and the realization of ideas, partly activities aiming at transformation of the students' attitudes and making them more responsible and purposeful. Finally, SABD wanted to convey knowledge of entrepreneurship by developing skills and attitudes in order to create "dynamic thinking and action" (Nutek 2008, p. 29).

\section{Pedagogies of Liberation?}

In the context of education policy, as well as in many other contexts, the entrepreneur appears as something of a "modern hero" (Styhre, 2005). In various policy documents, official reports and project plans highlighting the benefits of "entrepreneurship education" or "entrepreneurial learning" there is a clear and rather distinct "product" of such education outlined - the entrepreneur, the entrepreneurial student or individual (Leffler, 2006). He or she is portrayed as being flexible, creative, enterprising and independent, as having the ability to take initiative, solve problems and make decisions. Equipped with these "entrepreneurial abilities", he or she is referred to as being useful for the economy and therefore for society at large.

Entrepreneurial learning is about transforming no less then a wide range of the individual student's personality or self - and to make the individual more creative, autonomous, flexible and creative. Here, there is an idea that students with an "entrepreneurial approach" can overcome obstacles such as negative ideas, thoughts and habits. The ambition of "entrepreneurship education", however, is not only to develop the students but also to "liberate" them from their previous mentalities and conditions. In that regard, there are some striking similarities between the "entrepreneurial pedagogy" of today and the kind of "progressive pedagogy" that was developed in the beginning of the $20^{\text {th }}$ Century, which for instance had a huge impact in the development of the Swedish school system, particularly in the latter part of the $20^{\text {th }}$ Century (Hartman et al., 2005). "Progressive pedagogy" was char- 
acterized particularly by its focus on the student and his or her individual development (Arfwedson, 1998), which presupposes a certain degree of freedom and autonomy - and with this responsibility - in the learning process. Parts of this pedagogy can be understood as a reaction to previous educational doctrines and practices.

Hence, the achievements of a "progressive pedagogy" become visible in contrast to the drawbacks of the traditional counterpart. The advocates of entrepreneurial education use a similar rhetorical style when elaborating on an ideal Swedish educational system. In a way, it seems as if the language of "progressive pedagogy" and its way of conceptualizing of the autonomous and liberated subject, has been appropriated by neoliberal discourse. The entrepreneurial education is described as the opposite to traditional education found in the present Swedish school system (Leffler, 2006): entrepreneurial teaching is described as dialogical when traditional is monologic; entrepreneurial teaching is complete, traditional is amputated; the entrepreneurial student is professional and active, the traditional is passive. Adding entrepreneurship to education makes school more open, cooperative and adopted to reality, and less isolated and closed. Thus, entrepreneurial thinking helps the pupil to transcend the obstacles built up by negative thought patterns and liberates her or him from the negative impact of traditional teaching techniques. In this way, entrepreneurial education creates individual as well as societal value, according to their advocates.

\section{Concluding Reflections}

One of the purposes of entrepreneurial education is that the Swedish school system, to a greater extent than earlier, should collaborate with its societal surroundings, specifically the local (or regional) labor market. Following this rationale, local companies should be given the possibility to take part in and shape the activities at school. Networks should be established between schools, local companies and parents. Still, experiences from the National entrepreneurship program (Nutek, 2008), which took place in Sweden between 2005 and 2008, points in a slightly different direction. It seems that the contacts between schools and different NGOs or partnerships (between governmental, municipal and private bodies) specialized on entrepreneurial education was far more frequent than the contacts between schools and companies. The striving for partnership and cooperation with trade and industry boiled down to the adaption of a more business minded perspective in the local curricula. The idea of local networking, which had a central position in the general Swedish educational policy during the last decade, seemed to be less prominent in this particular context. 
Critics have pointed to the fact that the realization of the (fairly ambitious) learning outcomes of entrepreneurial education was not thoroughly discussed (Berglund \& Holmgren, 2007). What is lacking, though, is an elaborated discussion on the ways in which the learning activities might produce the competencies and qualities specified in the outcomes, such as flexibility, creativity, power of initiative, capability to solve problems, etc. Thus, an elaborated pedagogical model of how the activities would produce the outcomes is absent (ibid.). The outcomes were elaborated and discursively explicated in a comprehensive way; the descriptions of the learning processes were not. Discursively, the content of the learning activities was clearly subordinated to its outcome, the entrepreneurial individual. The end-product is central: the flexible, self-reliant and creative individual who enters the labor market, as an asset for the overall societal economy.

Promoting entrepreneurship at school is not a temporary venture. The current Swedish rightwing and neoliberal government has stated that "entrepreneurship should be the main thread throughout the educational system" (The Government Offices, 2009, p. 12). In that sense, we can discern the development of an entrepreneurial school system. A key feature in entrepreneurial teaching is the emphasis on economical utility and its priority over other values. The design of the teaching material - with its emphasis on creativity, flexibility and self-reliance - are directly related to its presumed utility on the labor market. Following Aihwa Ong (2006), we might see the entrepreneurial pedagogy, albeit its quality of being under-theorized, as a particular kind of governmentality, connecting students and their subjectivity to the rationality of the market. On the one hand, this specific pedagogy opens up spaces for entrepreneurship, in a spectrum ranging from the physical (for example, placements) to the imagined (pseudo-companies run by students). On the other hand, it also shapes entrepreneurial subjects, or entrepreneurs, with a specific set of qualities and competencies. The interventions made possible by entrepreneurial pedagogy are not confined to the arenas made up by the school system. Rather, they branch off out in the social body in its entirety and they involve a number of agents, governmental as well as non-governmental, regional as well as national or transnational, networks as well as individuals.

Connecting to the notions developed by Michel Foucault, it might be said that the entrepreneurial pedagogy is made up of technologies of the self as well as technologies of power. The governing made possible provides a "management of the self" where students cultivate and work over their selves, so that they can "optimize choices, efficiency, and competitiveness in turbulent market conditions" (Ong, 2006, p. 6), i.e. they become entrepreneurs. Through different technologies of the self, the students become autono- 
mous, responsible and able to adapt. At the same time, a utility perspective is emphasized, a perspective which recurrently stresses the demands and expectations of the labor market, and where the student is inscribed in an economical rationality. When those forms of citizenship gain ground, the citizen is remolded to an entrepreneurial subject, fostered in line with the imperatives of the "advances liberal society". "The enterprising self will make an enterprise of its life", notes Nicholas Rose (1998, p. 154), "seek to maximize its own human capital, project itself a future, and seek to shape itself in order to become that which it wishes to be".

With an increasing mobilization of entrepreneurship in school, older pedagogical and educational doctrines are challenged. Other visions, stating other educational purposes and goals emerge. In the vision of the entrepreneurial school, it becomes logical to emphasize the value education has for the economic system - and the companies inhabiting it. Considerations of economical utility are integrated with the other learning outcomes. The comparison with "progressive pedagogy" highlights this aspect. Although they show some (rhetorical) similarities, they differ in one fundamental aspect: in entrepreneurial education, the promise of emancipation from authoritarian teaching and education, and from its obstruction to personal development, are connected to economical utility. The promise of emancipation from traditional ways of teaching, as formulated by the progressive pedagogy, has been taken up (and co-opted?) by advocates of entrepreneurial pedagogy, of course with a subtle change. In the name of entrepreneurship, the inability of traditional pedagogy to develop the creativity, initiative and belief in the future is emphasized. The promise of emancipation is re-written; from now on, it is a matter of emancipation and entrepreneurship, or, rather, emancipation through entrepreneurship. Here, education becomes emancipation though enterprise.

\section{References}

Andersson, R. (2006). The unveiling of merit. In T. S. Popkewitz (Ed.), The future is not what it appears to be. (pp. 62-83). Stockholm: HLS.

Arfwedson, G. (1998). Undervisningens teorier och praktiker, Stockholm: HLS.

Berglund, K., \& Holmgren, C. (2007). Entreprenörskap och skolan - vad är det lärare berättar att de gör när de gör entreprenörskap $i$ skolan, Stockholm: Forum för småföretagsforskning.

Dahlstedt, M. (2009). Governing by partnerships. In Journal of Education Policy, 24(6), 787-801.

Dahlstedt, M., \& Hertzberg, F. (2011). Skola i samverkan. Malmö: Gleerups. 
Dahlstedt, M., \& Tesfahuney, M. (2010). Speculative pedagogy. In Journal for Critical Education Policy Studies, 8(2), 249-274.

Dean, M. (1999). Governmentality. London: Sage.

Ds (1997). I entreprenörskapets tecken. Stockholm: Fritzes.

Englund, T. (1994). Education as a citizenship right. In Journal of Curriculum Studies, 26 (4), 383-399.

Esping-Andersen, G. (1990). The three worlds of welfare capitalism. Oxford: Polity Press.

Fejes, A., \& Nicoll, K. (Eds.) (2008). Foucault and lifelong learning. London: Routledge.

Foucault, M. (1988). Technologies of the self. In L. H. Martin, H. Gutman, \& P. H. Hutton (Eds.), Technologies of the self. (pp. 16-49). London: Travistock.

Foucault, M. (1991). On governmentality. In G. Burchell, C. Gordon, \& P. Miller (Eds.), The Foucault effect. (pp. 87-104). Brighton: Harvester.

Gillies, D. (2011). State Education as high - yield investment. Journal of Pedagogy, 2 (2), 224-245.

Government Communication. (1996/97): 112. Utvecklingsplan för förskola, skola och vuxenutbildning.

The Government Offices. (2009). Strategi för entreprenörskap inom utbildningsområdet. Stockholm: The Government Offices.

Hartman, S., Lundgren, U. P., \& Hartman, R. M. (2005). Inledning. In Dewey, J., Individ, skola, samhälle. Stockholm: Natur och kultur.

Henry, C., Hill, F., \& Leitch, C. (2001). Entrepreneurship, education and training. Aldershot: Ashgate.

Holmgren, C., \& From, J. (2005). Taylorism of the mind. European Educational Research Journal, 4 (4), 382-390.

Hultqvist, K., \& Petersson, K. (2000). Iscensättningen av samhället som skola. In J. Bjerg (Ed.), Pedagogik. (pp. 496-527). Malmö: Liber.

Johannisson, B., Madsén, T., \& Wallentin, C. (2000). Aha! Företagsamt lärande. Stockholm: Utbildningsradion.

Leffler, E. (2006). Företagsamma elever. Umeå: Umeå University.

Lindensjö, B., \& Lundgren, U. P. (2000). Utbildningsreformer och politisk styrning. Stockholm: HLS.

Lundahl, L. (1997). A Common denominator?. International Journal of Training and Development, 1 (2), 91-103.

Mahieu, R. (2006). Agents of change and policies of scale. Umeå: Umeå University.

Nutek. (2007). Så tänds eldsjälar. Stockholm: Nutek.

Nutek. (2008). Entreprenörskap i stort och smått. Stockholm: Nutek.

Nyström, E. (1999). Entreprenörskap i skolan. Stockholm: Stiftelsen Institutet för individanpassad skola. 
Olsson, U., Petersson, K. (2008). The operation of knowledge and construction of the lifelong learning subject. In A. Fejes, K. Nicoll (Eds.), Foucault and lifelong learning. (pp. 61-73). London: Routledge.

Ong, A. (2006). Neoliberalism as exception. Durham: Duke University Press.

Piore, M. J., \& Sabel, C. F. (1984). The second industrial divide. New York: Basic Books.

Popkewitz, T. S. (2002). Pacts/partnerships and governing the parent and child. In Current Issues in Comparative Education, 3 (2), 122-130.

Popkewitz, T. S., \& Brennan, M. (1998). Restructuring of social and political theory in education. In T. S. Popkewitz, M. Brennan (Eds.) Foucault's challenge. (pp. 3-35). New York: Teachers College Press.

Prop. (1995/96: 222). Vissa åtgärder för att halvera arbetslösheten till år 2000, ändrade anslag för budgetåret 1995/96, finansiering m.m. Stockholm: Fritzes.

Rose, N. (1996). Governing "advanced" liberal democracies. In A. Barry, T. Osborne, $\&$ N. Rose (Eds.), Foucault and Political Reason. (pp. 37-64). London: Routledge.

Rose, N. (1998). Inventing ourselves. Cambridge: Polity Press.

Rose, N. (1999). Powers of freedom. Cambridge: Cambridge University Press.

Simons, M., \& Masschelein, J. (2008). The governing of learning and the learning assemblage of a learning apparatus. Educational Theory, 58 (4), 391-415.

SOU (1997: 121). Skolfrågor. Skolkommittén. Stockholm: Fritzes.

Stevenson, L. A., \& Lundström, A. (2002). Beyond the rhetoric. Stockholm: Swedish Foundation for Small Business Research.

Styrhe, A. (2005). Ideology and the subjectification of the entrepreneurial self. In International Journal of Management Concepts and Philosophy, 1 (2), 168-173.

Svedberg, G. (2007). Entreprenörskapets avtryck i klassrummets praxis. Umeå: Umeå University.

Tesfahuney, M., \& Dahlstedt, M. (Eds.) (2008). Den bästa av världar?. Stockholm: Tankekraft.

\section{Authors:}

Magnus Dahlstedt, Associate Professor

Linköping University

Philosophical Faculty

Department of Social and Welfare Studies

Holmentorget 10

Norrköping

60174

Sweden

email: magnus.dahlstedt@liu.se
Fredrik Hertzberg, PhD., Senior Lecturer

Stockholm University

Faculty of Social Sciences

Department of Education

Frescativägen 54

Stockholm

10691

Sweden

email: fredrik.hertzberg@edu.su.se 